\title{
7. STYLISTIC CONSIDERATIONS ON SCENE NO. 8 FROM THE MUSICAL PERFORMANCE PRETIOASELE RIDICOLE [THE AFFECTED YOUNG LADIES] BY VASILE SPĂTĂRELU
}

Alexandru Radu Petrescu

\begin{abstract}
Molière is one of the playwrights who not only marked and defined the seventeenth century in France, but, creator of the modern comedy and discoverer of the authentic comic, contributed fully to educating the public in his present and for the future. His comedies have stood the test of time, as they resonated with the audience, which found itself in them. In the twentieth century, his plays entered the artistic territories adjacent to the theater trough other creators, who turned them into film scripts and librettos for musical theater. The subject of our research is a fragment pertaining to the farcePrețioasele ridicole [The Affected Young Ladies] turned into a musical show under the signature of Vasile Spătărelu. An important name in Romanian music, creator with great melodic imagination, harmonic refinement and perfect literary taste, the composer from Iași made a possible compositional model for the genre, which is part of the Romanian musical show's route opened by Paul Constantinescu and Pascal Bentoiu. His work is distinguished by the stylistic area to which it adheres, by rhythm and vivacity, by the original combination between the spoken and the sung text, by the ingenious architecture of the scenes, by the adequacy of the writing technique to the desired effect and expression. Fully requesting all the resources of the interpreters, we consider that the analysis of the important moments is very useful to them. If pages of theatrical exegesis were dedicated to the characters Magdelon and Cathos, for Mascaril we did not identify something similar, much less a stylistic-interpretive analysis from a musical perspective. In order to achieve a complete characterization of the character, useful to potential student performers, we will comment on the first segments of the Scene no.8 in which Mascaril's "identity" is established, as he presents himself in front of the two "precious ones". (the entrance and the monologue).
\end{abstract}

Key words: The Affected Young Ladies, Molière, Vasile Spătărelu, Mascaril, stylistic considerations

\section{Argument}

Our study proposes to contribute to the theoretization of some aspects in regards to the musical play Prețioasele ridicole [The Affected Young Ladies] by Vasile Spătărelu, with a focus on the character Mascaril, through stylisticinterpretative analysis of the scene in which he presents himself to the "pretentious" Cathos and Magdelon. Taking into account the scarcity of Moliere's texts in Romanian musical theater and the absence of some similar research into the male/masculine characters of the farce Les Précieuses ridicules [The Affected Young Ladies], our endeavor is aimed, primarily, towards students and potential interprets. Reiterating some aspects in regards to the French playwright, his creation and characters is absolutely necessary for the understanding and veridical interpretation of the characters built by the Romanian composer. His personal experience as an actor, which he made use of akin to Shakespeare, helped Molière in perfecting his literary-dramatic technique and create some exceptional

19 Associate Professor PhD., "George Enescu" National University of Arts from Iași, Romania, email: alrapet@yahoo.com 
characters, him being often considered "not [...] only the author and actor of genius, [but] also a great schoolmaster of masterful acting" $"$.

\section{Introduction}

Molière (Jean Baptiste Poquelin) is one of the defining landmarks of the $17^{\text {th }}$ century French literature, alongside Pierre Corneille, Jean Racine, La Bruyere, La Rochefoucauld, and La Fontaine. More so, creator of modern comedy, he is an essential name in the universal dramaturgy alongside Shakespeare, Cervantes, Dante and Goethe. Through his work, he remained "a great contemporary of all times" 21 , as does the actor Ion Finteșteanu rightfully remarks, a great Romanian interpret of Molière's characters.

Of the 36 plays by Molière, Les Précieuses ridicules (played in 1659 and published in 1660) was the eighth, the one with which the author registered his first resounding success. As it is well known, "it is also a first success of French comedy, that presents with itself a new trend: observation through caricature." 22 The farce in one act Les Précieuses ridicules was an event in the history of drama, the first satirical comedy of morals/manners, a synthesis between the French farce, comedia dell'arte and the morals/manners comedy. Denouncing the excess of preciousness in the high society of the time, Molière attacks with no gloves the snobbish and superficial nobility. His characters are clearly sketched and provoke laughter through the mirroring of behavioral excesses using all the resources of the comic. The theme of preciousness did not run out after this farce, but, preferred by the playwright, it came back in La Comtesse d'Escarbagnas (1671) and in Les Femmes savants (1672).

In the $20^{\text {th }}$ century, alongside the non-interrupted representations of Molière's plays, his work traversed time. It perpetuated itself in this new context as a known and archived cultural legacy, put in relationship with the novelty of language, of the specific communication layers ${ }^{23}$. Contemporary creations pertaining to some artistic territories adjacent to theater have brought value to Molière's comedies through filmic approaches, radio-theater adaptations and, not lastly, through the transformation of some drama plays into libretto for musical theater.

In Romania, radio-theater first prezented the farce Prețioasele ridicole [The Affected Young Ladies], in 1959 (translation and radio-phonic adaptation by George Teodorescu) with a distribution which the history of dramatic play considers ideal - Nicolae Gărdescu, Eugenia Popovici, Nineta Gusti, Radu Beligan, Grigore Vasiliu-Birlic, Mircea Constantinescu, Alexandra Polizu, Mihai Fotino, Mircea Anghelescu, Ion Lucian - and it can be considered a model of text delivery. In regards to the musical theater show, as was on other meridians of the

\footnotetext{
${ }^{20}$ Ion Finteşteanu, De la clovnul citire...[From the clown's reading], Sport Turism Publishing House, Bucureşti, 1982, pp. 203-204

${ }^{21}$ Idem, p. 205

22 Sorina Bercescu, Istoria literaturii franceze [History of French literature], Scientific Publishing House, București, 1970, p. 200

${ }^{23}$ The term belong to the composer Theodor Grigoriu, for clarifications pentru clarificări see the works Muzica şi nimbul poeziei [Music and the halo of poetry], Music Publishing House, București, 1986 and Internet, Editions Musicales Transatlantiques Paris, Larghetto Amsterdam, ArsSonora București, 2007
} 
globe ${ }^{24}$, Romanian composers approached a piece of work with such a savory and complex, in its simplicity, comic as Les Prtcieuses ridicules with a level of precaution. The research indentified only the musical performance Prețioasele ridicole by Vasile Spatarelu (1985). Previously, Pascal Bentoiu stopped over Molière's dramaturgy, composing his own libretto after Molière, the comic opera in one act Amorul doctor op.15 (1964).

With a discreet biography, but a pregnant pedagogic, artistic, and spiritual presence in the Iași’s cultural community, the composer Vasile Spătărelu (19382005), "a continuator of the Achim Stoia generation - George Pascu [...] managed to become Iași's leader of the creational group from the capital of Moldova, his work covering all musical forms and genres [even being considered] a new and valued Romanian continuator of the genius precursor from the land of Moldova" ${ }^{25}$, George Enescu. Learnt and made at the Conservatory in Bucharest under the the influence of Anatol Vieru's modernity and his accentuated interest for the new music of the representative creators of the period, Spătărelu is part of the second generation of composers after The Second Word War whom, in the $7^{\text {th }}$ and $8^{\text {th }}$ decades, porposed their own orientations ${ }^{26}$.

Prețioasele ridicole is a singular (unfortunately) and superb creative adventure in the genre of musical theater, interesting for interprets, through its interpretative plurivalence required by the complexity of Molière's roles, as well as theoreticians in the field, through the original synchronization with the international musical field. Anticipating the stylistic and aesthetic postmodern valences, the composer subtly unravels an unexpected continuinty and novel connection in correlation with the social and artistic past.

Situating itself in trend with the Romanian musical spectacle of the $20^{\text {th }}$ century, with the literary taste of a stylish bibliophile, it is proposed to us a (re)lecture of a classic theater piece. "Engaged" by the scene music composed beforehand (13 reference creations for text from the Romanian and universal dramaturgy) and having notable realisations in the musical genres with vocal implication (vocal-symphonic, choral, vocal-chamber music), Spătărelu realizes a possible compositional model of the genre which fits on the open direction in the Romanian music by Paul Constantinescu and Pascal Bentoiu, followed afterwards by other composers, of which we mention Dan Dediu.

\section{Discussions}

The novelty of the proposed spectacle model provoked a divide in opinion with regards to its framing in the musical theater (sub)genre. After musicologists Viorel Cosma and Mihail Cozmei - the latter having the piece dedicated to him -

\footnotetext{
${ }^{24}$ François Devienne (1759-1803), French composer nicknamed by French musicologists „French Mozart”, composed among his 12 works Les précieuses ridicules (1791), opera in one act, with a libretto by Pierre Louis Moline; Felice Lattuada (1882-1962) composed the lyrical comedy in one act Le preziose ridicole (premiera at La Scala in Milan, february 9, 1929), with a libretto by Arturi Rossato; the American composer John Laurence Seymour (1893-1986) created Les précieuses ridicules (1920) on his own libretto; Judith Shatin Allen composed the opera Follies and fances (1981) after Les précieuses ridicules.

${ }^{25}$ Viorel Cosma, Muzicieni din România: lexicon biobibliografic [Romanian musicians: biobibliographic lexicon], vol. 8, Music Publishing House, București 2005, p. 270

${ }^{26}$ For details see Valentina Sandu-Dediu, Muzica nouă intre modern și postmodern [New music between modern and postmodern], Music Publishing House, București, 2004, p. 154
} 
they took on the designation of musical spectacle ${ }^{27}$ in accordance to the subtitle in the score. Ruxandra Arzoiu appreciates Prețioasele ridicole as "a musical commentary full of zest [...] in the form of a musical in the modern sense of the term, in which musical moments of contemporary expression [...] are entwined with prose dialogue lifted as they were in the original text" ${ }^{28}$. From our point of view, even if both framings can uphold their legitimacy, we prefer the opinion of the composer. We don't do this to avoid polemic, but because, as the composer Dan Dediu affirms, the subtitle is an important aspect of the imagined music ${ }^{29}$, in our case, anticipating the entire theatrical performance (music, text and image). And because, in our opinion, the work adheres to the stylistic area of chamber opera (length, number of characters, orchestral ensembly ${ }^{30}$ ), having minimal reference to the instrumental theater genre (granting dramatic qualities to instruments and attributing spoken lines to instrumentalists and the conductor), the whole serving to put into play the spectacle.

In a work in which "adjacent arts" 31 intertwine in a two way potentiation, the theatricality of Spătărelu's music remarks itself as dominant and determinating, a true catalyst for the ulterior scenic realisation. Profousely original, it flows from the complex nature of the literary text (scenes with proceedings and unfoldings specifics to the farce: expositive segments of presenting the characters, followed up by the action which provokes the conflict and mishaps, and the final segment in which the characters are unmasked and the whole situation is solved), the musical images carrying theatrical valence. Work in the improvisation medium of theater was favourable and generated a specific imprint in the approach of the text-music binominal.

The whole work gives off the impression of a joyous improvisation, of a participation to Molière's farce. Spătărelu's honest and subtle humour is contagious. There is a note of accessibility that convices and attracts both the interprets and the public. "Expressive and singable, vigorous and picturesque, of a sharp irony or with grotesque hints, music composed by Vasile Spătărelu captures with its natural expressivity and efficiency, through its savant but clear script, through its power of underlining and potentiating the comic of scenic action, the foolishness of some characters" ${ }^{32}$. Surprisingly, lacking in self repetitiveness, triviality, and predictibility, in spite of the quoting the composer resorts to in the scope of realizing a distinct expressive value.

Lecturing Molière's text in the musical vision of Spătărelu means a notable and essential balance between the musical and dramatic structure, between the

\footnotetext{
27 Cf. Viorel Cosma, Muzicieni din România: lexicon biobibliografic [Romanian musicians: biobibliographic lexicon], vol. 8, Music Publishing House, București 2005, vol. 8, p. 270 and Mihail Cozmei, Existențe și împliniri. Dicționar biobibliografic, [Existences and accomplishments. Biobibliographic dictionary], second edition, Artes Publishing House, Iași, 2010

${ }_{28}$ Ruxandra Arzoiu, Opera de cameră românească [Romanian chamber opera], Music Publishing House, București, 2002, p. 56

${ }^{29}$ See Dan Dediu, Radicalizare și guerilla [Radicalization and guerrilla warfare], Music Publishing House, București, 2004, pp. 11-20

${ }^{30}$ Strings $(4+3+2+1+1)$, flute, oboe, clarinet, bassoon, horn, trumpet, trombone, tuba, percussion (small drum, big drum, chestnuts, triangle, xylophone, gong, cinelli, rock drums)

${ }^{31}$ See Anatol Vieru, Cuvinte despre sunete [Words about sounds], second edition, Glissando Publishing House, București, 2008

${ }^{32}$ Mihail Cozmei, O premieră absolută, [An absolute premiere], în „Cronica” [“The Chronicle”], July 26,1985, Iași
} 
rhythm of action running its course and storytelling, and the specific correspondence with musical aspects (rhythm, meter, agogics, dynamic). Harmonic directionality and formal articulation that breaks strict patterns are subordinate to a farce's architecture. The alternation between vocal-instrumental and instrumental musical section, and the dramaturgical (spoken text), in the economy of the play and for every role in part, doesn't lead to a fragmentation but a remarkable and complex coherence of character and performative construct.

Musical sections are firmly controlled by the composer through agogics and duration, through metro-rhythmical elements used for the benefit of the theatral message. The balance of the structural whole comes from its dynamic, from the text-music, voice-instrument, play-song-talk relations, through finely dosage of what others might call excess. For example, while Lully composed for the finale of Molière's comedies a Courante, Spătărelu brings rock rhythms (in scene 11). What seems not only surprising, but excessive in the historical context of Romania in the year of 1985, today it no longer provokes exclamation, but only a wide smile. Spătărelu reacted superbly to characters and dramaturgical intention. $\mathrm{He}$ associated the right instrument to every theme, character, state, and dramaturgical situation, obtaining in the same time the useful service of the comic's orchestration and the configuration of a unifying sound palette of the dramatic text.

If for Magdelon and Cathos, the two province "precious", pages of exegesis were written, and theatral chronicles dedicate generous spaces to them, Mascaril, the one who "provokes" the action in the play, is far less commented. In our opinion, the theoretical elements complement in a necessary way the interpretative investigation needed to properly realize the role in from a scenic perspective. Mascaril is a superb character, offering, foregoing Scapin and Figaro, who offers the interpret possibilities to "school himself" and shine.

Scene $n r .8$ of the musical show Prețioasele ridicole establishes the character of Mascaril's identity, as he presents himself in front of the two province "precious", Magdelon and Cathos. With gestures and movements fundamentated in the sound structure, the valet disguised as a marquis (no more or less that The Marquis of Mascaril!) makes his appearance on an 16 measures instrumental introduction. After Molière's model, who generously noted scenic indication on the text, Spătărelu notes his own suggestions, so we realize we are dealing with a "saloon music, exaggerated and comical reverences the characters make to one another, in a manner as grotesque as possible" ${ }^{33}$. Thus it is already delimited the stylistic area in which we can expect the musical material to be "laid". Even after a glossing look over the musical sample, we have an insight of the branch (still) opened by Molière's work which, after the observation of Costin Tuchilă, "does not circumscribe itself to any space nor time, [but] expresses the past, prezent, and $[\ldots]$ the future" 34 . Musically, the composer follows the steps of his forerunners,

\footnotetext{
33 Vasile Spătărelu, Prețioasele ridicole [The Affected Young Ladies], the version for voices with piano accompaniment, manuscript, library of the "George Enescu" National University of Arts, Iași, România, p. 22

${ }^{34}$ See Costin Tuchilă and Pușa Roth, Clasicii dramaturgiei universale, [Classics of universal drama], vol. 1, chapter Molière - Fiziologia râsului [Molière - the physiology of laughter], romanian Academy Publishing House, București, available at https://costintuchila.wordpress.com/2011/06/13/moliere-\%E2\%80\%93-fiziologia-rasului/, accessed on 27.09.2020 and at https://pusaroth.files.wordpress.com/2011/06/moliere-fiziologia-rasului.pdf, accessed on 15.10 .2020
} 
Paul Constantinescu and Pascal Bentoiu. As is the case with the creations of those before him, here the quoting in the postmodern manner of well known musical fragments, from different styles, comes the basic characteristic of a musical discourse. Combining quotes through juxtaposition, superposition, cropping, permutation, in a true sound mosaic, determinates a polystylistic character, with direct hints to composers like Bach and Beethoven. Having the privilege of meeting master Spătărelu, we cannot refrain from mentioning the voluptuousness of using quotes, to the tricksy joy of observing with squinted eyes the effect it produces, looking over the frame of his glasses.

The pompous entrance of Mascaril is announced by grotesque and festive sounds of a Slow Minuet. The gracious, gallant nature of the old dance was mutilated, deformed, and substituded with a charicature, in consensus to the disproportionate and ridiculous attitude of the character. The movement and gestures are determined by a sound structure, outlining a complex, contrapuntal relationship between sound and gesture, one of parallelism and complementarity alike.

The first sequence of this scene represents the musical characterization of the fake Marquis of Mascaril (baritone). Afterwards, he is musically personified through the leitmotif grafted to the figure akin to an arpeggio (in $\mathrm{C}$ major), extracted from the Minuet in G major from Album for Ana Magdalena Bach. The leitmotif accompanies the blunt manner of speak of the character in cause: "I am The Marquis of Mascaril"

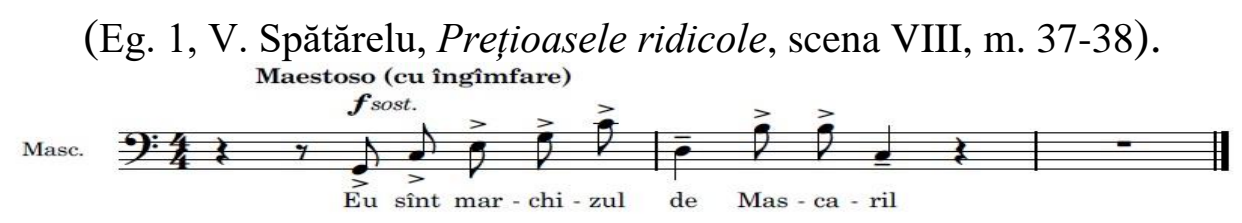

After all, the whole melodic material of the menuet is a parody if the Bach influenced source previously mentioned, with the mention that the incipient phrase appears as an ingenious motif permutation, proff that the music "also sits by itself this way". Thusly, sequence on 3-4-5-6 measures, from the Bach original, is permutated into a 4-5-6-3 formula

(Eg. 2, V. Spătărelu, Prețioasele ridicole, scena VIII, m. 1-4).

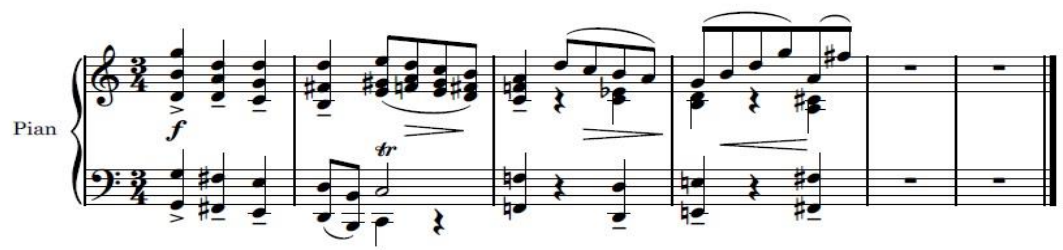

The incipient phrase in 4 measures is spoken three times, with measurement enlargements (4 measures +6 measures +6 measures) and placement of three tonal centers: initially $\mathrm{G}$ major, then $\mathrm{B}$ flat major, A major. Harmonical structures (alterated chords) and chord relationships (substitution of main steps with the secondary ones at key moments, in accentuated times, plagal relations, chord layer) are also modified, as it is, for example, in the analysis of the first two measures, which mainly evolve on the predominantly plagal relationship I - V6 IV/I - III - IV5\#. Aiding the illustration of a disharmonious, strident musical expression, hyperbolic images and metaphors with an expressionistic tendency are used. 
For highlighting the characteriological intentions, it resorts to rhetorical symbols with an emphatic, bombastic characters, which enhance the affected manner of expression, the ridiculousness and preciousness of the sitautions and attitudes. The rhetorical symbols are powerful instruments with an immediate impact on the listener, with powerful persuasion effects ${ }^{35}$. From them, we can enumerate the following:

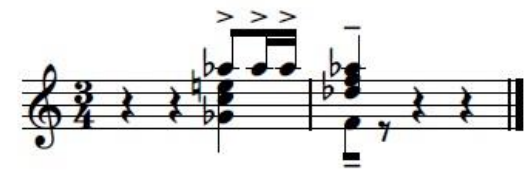
thickening the melody in sound mixes, which encumbers the original character of the dance; encumbering the low sound registry through doubling the octaves; the use of some powerful nuances, especiale the forte; the ridiculus appartion of a trill in the measurements 2, 6, 12; the strident and heavy dynamic (accents and portato); the shocking inserts of the dactyl cell in measure 9, which appreas like "a nut in the wall" and destabilizes us with its martial hint of a marching band in the context of the ternary metric of the dance (Eg. 3, V. Spătărelu, Prețioasele ridicole, scena VIII, m. 9-10); Rhythmic decreases in sixteenths, artificial, emptied of substance, in measures 10 and 16

(Eg. 4a și 4b, V. Spătărelu, Prețioasele ridicole, scena VIII, m. 10 și m16).
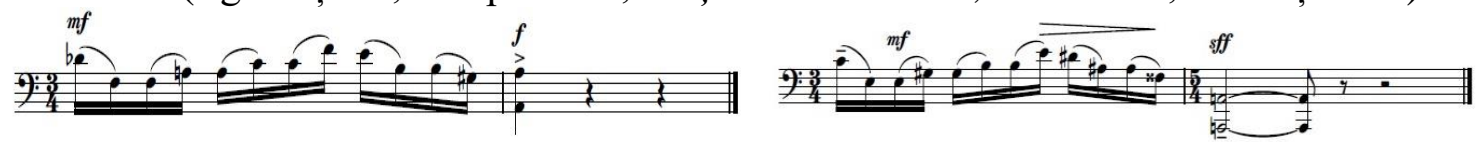

From the slow minuet it suddenly deviates - with a pedal stop in fortissimo $s f f$ - to Mascaril's monologue. Here it makes work of an arsenal of suggestive expressions which truthfully follow the meanders of the text and its prosodic accent. The notes' values are decided upon in conformity to the sense of the words vehiculated in text. It does not shy away from sung dialogue, the dynamic of contrasts, the effect of pauses. The surprising moments of silence, fertile, "fulled" with meaning and play, fully serve the comic. Mascaril makes his pompous debut (risoluto, sost.), strident, excessive on the defective scale of an acoustic mode 7, which relevates the sharpness of an enlarged quart and fifth

(Eg. 5, V. Spătărelu, Prețioasele ridicole, scena VIII, m. 17-18).

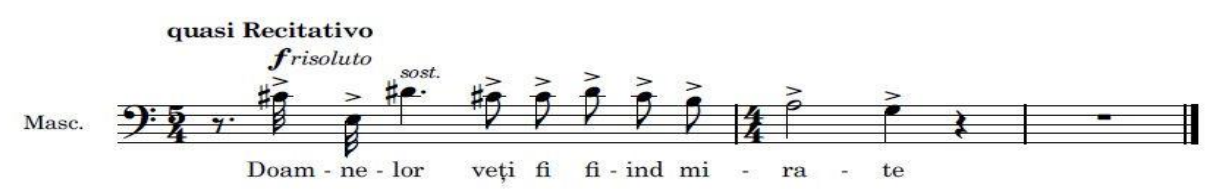

The initial harmonical isorhythmia now subsides in place of dialogue, between the singable delivery of the character (quasi recitativo) and the interventions of the orchestral accompaniment which reiterates the motive of the minuet, often in various overlapping cutouts

(Eg. 6, V. Spătărelu, Prețioasele ridicole, scena VIII, m. 19-20).

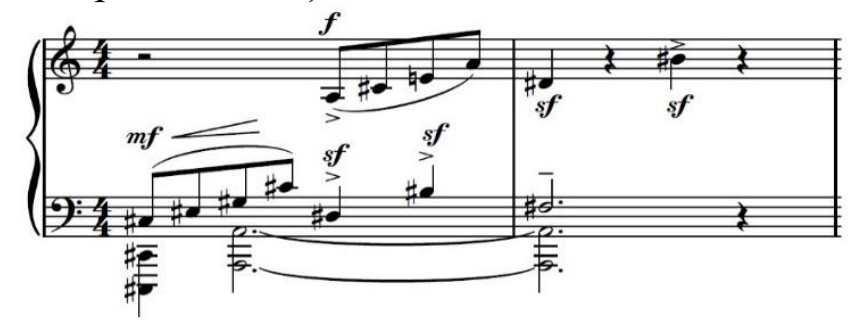

Intonations located at the border of exaggerated declamation cause the

\footnotetext{
${ }^{35}$ Patrick Saint-Didier, Musical Rhetoric. Foundations and Annotation Schemes, London, ISTE Ltd., 2014, p. 160
} 
composer to resort to specific ornaments, such as portamento or glissando. Despite his vocal discourse seemingly pulverized by rhythm and fragmented by instrumental comments, the performer of the role Mascaril must achieve continuity in expressing dramatic musical ideas. This musical-dramaturgical coherence presupposes/ involves an important and sustained vocal and physical effort. From now on, the motifs of the minuet are shattered in shards and clumsily reconstructed, anarchic, disordered

(Eg. 7, V. Spătărelu, Prețioasele ridicole, scena VIII, m. 22-23).

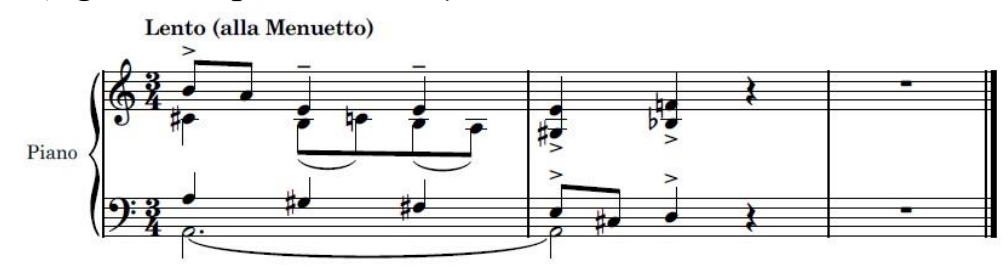

The action is precipitated by accumulations in waves towards climaxes, eached either by vertical increases of the speech density, or by horizontal rhythmic decreases: motor-visual metaphors are inserted in the musical discourse, such as the rows of sixteenths attached to the sequence "so that I run everywhere after it". The comic of the situation is doubled by the melodic profile of the sequence, equivalent to the Beethoven motif of destiny, modified, however, on the heel of a harmonic structure of major-minor type, in which one feels the false relationship e-e flat

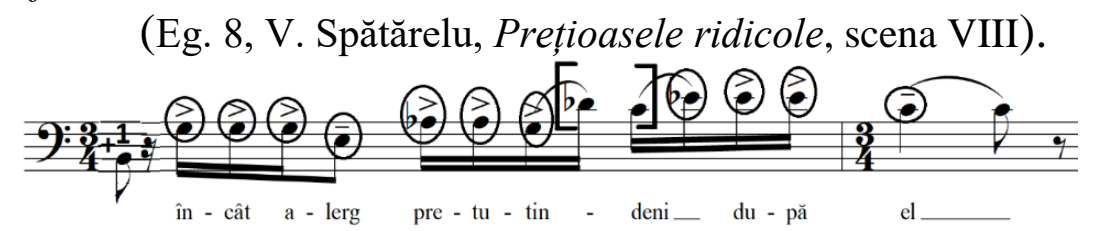

Starting with the section in which Mascaril reveals his identity (bearing the indication Maestoso - with pride), we will be partakers of a paroxysmal accumulation, achieved/ performed by repeated escalations of the acute register, to the limits of the falsetto voice. It is the steepest ascending slope of the whole number, which the text rafted on the anaphoric rhetorical figure (the repetition with intensification of the poetic-musical effect) claims: "I am the Marquis of Mascaril, a man of soul, a man of spirit, a man of letters, a poet of great fame , a composer and many more..." The ambitus gains ground, with each enumeration of the virtues of the important character: the steps that will be reached, gradually, are both $b$ flat $-d^{l}-f^{l}-a^{l}$ - and $b f_{l a t}{ }^{l}$ (score, measures 38-44). The performer must overcome here the difficulties of register jumps, maintaining the vocal homogeneity and timbre quality of the sounds emitted, even if he forces the extremities of the ambitus of the baritone voice (emitted in full voice, falsetto or head voice). The fragment culminates with a passionate tirade consisting of sixteenths, which the charming character utters in one breath: "and I have come to lay to your feet..."

(Eg. 9, V. Spătărelu, Prețioasele ridicole, scena VIII, m. 48-49).

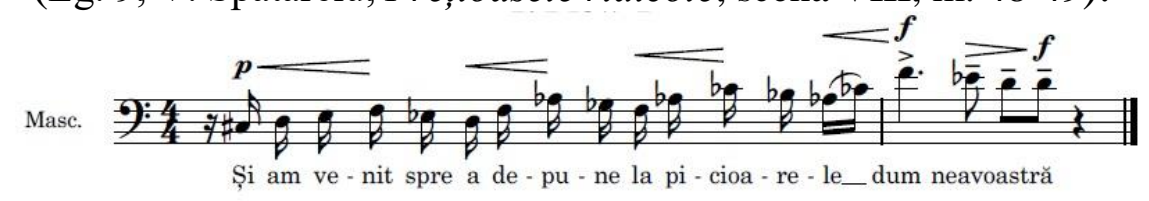


Resolving the tension of the moment through the phrase "much deserved tributes", it melodically molds on the reversal of Mascaril's leitmotif

(Eg. 10, V. Spătărelu, Prețioasele ridicole, scene VIII, m. 49-51).

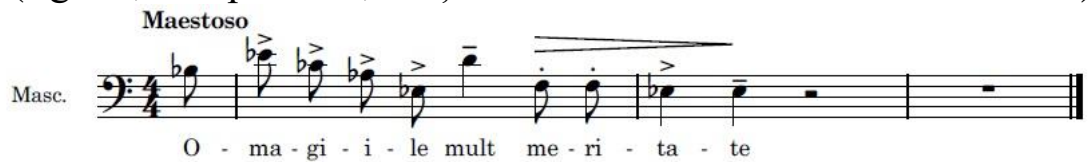

Impressed, the precious ones urge the marquis to use the "facilitator of speech" in a duet intervention, intensely chromated, where the vocal part has a sinuous profile, mostly descending (suggesting the honeyed and hypocritical endearment of some cats) and fragmented bypauses (suggesting the emotion produced by the Marquis of Mascaril). A rough major-minor chord $(d-f$ - $b$ flat $-d$ flat) suddenly ends the moment.

\section{Conclusions}

Through the musical show Prețioasele ridicole [The Precious Ridiculous], the composer Vasile Spătărelu successfully faced the challenge of modern music to be written to be sung. As if he had witnessed the notorious discussion between Glazunov and Shostakovich, in which the former advised the latter to consider that each piece meant a way of solving a composition problem, Spătărelu solved in an interesting contemporary musicalization of Molière's farce; he acted in the spirit of modernity by (re)reading a classic text and chose a polystylistic manner of treatment, specific to postmodernity.

Following a seductive compositional approach, with a certain vocative meaning for performers and audiences, resulted a unique and engaging perspective on the play, in which the distribution of constructive elements in musical time is perfectly intuited, with grace and a sense of fairness. For performers, the interpretive investigation on Moliere's characters in Spătărelu's musical vision and their interpretation means the assimilation and application of complex manners of singing and acting, specific to the genre (breathing, broadcasting, vocal technique, stage movement), a gain reflected in individual experience.

\section{References}

1. Arzoiu, Ruxandra (2002), Opera de cameră românească [Romanian chamber opera], Music Publishing House, București

2. Bercescu, Sorina (1970), Istoria literaturii franceze [History of French literature], Scientific Publishing House, București

3. Cosma, Viorel (2005), Muzicieni din România: lexicon biobibliografic [Romanian musicians: biobibliographic lexicon, vol. 8, Music Publishing House, București

4. Cozmei, Mihail (2010), Existențe și împliniri. Dicționar biobibliografic, [Existences and accomplishments. Biobibliographic dictionary], second edition, Artes Publishing House, Iași

5. Cozmei, Mihail (1985), O premieră absolută [An absolute premiere], în „Cronica” ["The Dhronicle”], July 26,1985, Iași, România. 
6. Dediu, Dan (2004)Radicalizare și guerilla [Radicalization and guerrilla warfare], Music Publishing House, București

7. Finteşteanu, Ion (1982), De la clovnul citire...[From the clown's reading...], Sport Turism Publishing House, Bucureşti

8. Grigoriu, Theodor (1986), Muzica și nimbul poeziei [Music and the halo of poetry], Music Publishing House, București

9. Grigoriu, Theodor (2007) Internet, Editions Musicales Transatlantiques Paris, Larghetto Amsterdam, ArsSonora București

10. Saint-Didier, Patrick (2014), Musical Rhetoric. Foundations and Annotation Schemes, ISTE Ltd., London

11. Sandu-Dediu, Valentina (2004), Muzica nouă între modern și postmodern [New music between modern and postmodern], Music Publishing House, București

12. Spătărelu, Vasile (1985), Prețioasele ridicole [The Affected Young Ladies], the version for voices with piano accompaniment, manuscript, library of the "George Enescu" National University of Arts, Iași

13. Tuchilă, Costin și Roth, Pușa (2010), Clasicii dramaturgiei universale, [Classics of universal drama], vol. 1, chapter Molière - Fiziologia râsului [Molière - the physiology of laughter], romanian Academy Publishing House, București, at https://costintuchila.wordpress.com/2011/06/13/moliere-\%E2\%80\% 93-fiziologia-rasului/, download 27.09.2020 and at https://

pusaroth.files.wordpress.com/2011/06/moliere-fiziologia-rasului.pdf, download 15.10.2020

14. Vieru, Anatol (2008),Cuvinte despre sunete [Words about sounds], second edition, Glissando Publishing House, București 